Avalaible online: https://ejournal.iai-tribakti.ac.id/index.php/pgmi

Article doi: https://doi.org/10.33367/jiee.v1i2.892

I Submission: 2019-09-06 I Review: 2019-09-07 I Accepted: 2019-09-28 I

\title{
Penggunaan Media Peta Berbasis Google Earth Di MIN 2 Kota Kediri
}

\author{
Muhammad Ahmad Sukron, ${ }^{1}$ Moh. Turmudi ${ }^{2}$ \\ ${ }_{1}^{1}$ Madrasah Ibtidaiyah Negeri 2 Kediri, ${ }^{2}$ Institut Agama Islam Tribakti Kediri \\ 1achunksoekron@gmail.com; 2moh.turmudi58@gmail.com
}

\begin{abstract}
The importance of a technological approach to management is to be able to help the educational process that is in line with educational goals. By using learning media through google earth-based maps, able to overcome the problems faced by teachers in delivering material about social science subjects. The focus of this research is to describe the design of planning; implementation, and factors that support and hinder teachers in implementing learning. This research uses a qualitative approach and this research is descriptive in nature. In collecting data using methods of observation, interviews, questionnaires and documentation. The results of this study include: first, determining the type of learning media, making learning plans, paying attention to the learning objectives in choosing media, recognizing the characteristics of students and learning media; second, techniques for managing interactive classes, steps for presenting teaching material, and responding to student characteristics; and third, supporting factors include: madrasas provide facilities, adequate teacher quality, student interest in instructional media, student motivation, student seriousness to pay attention to the material, and its effect on student learning outcomes. While the obstacle is inadequate infrastructure, and the expertise of teachers has less experience in operating Google Earth media.
\end{abstract}

Keyword: Teacher, Learning Media, Google Earth

\begin{abstract}
Abstrak
Pentingnya pendekatan teknologi dalam manajemen adalah untuk dapat membantu proses pendidikan yang sejalan dengan tujuan pendidikan. Dengan menggunakan media pembelajaran melalui peta berbasis google earth, mampu mengatasi masalah yang dihadapi oleh guru dalam menyampaikan materi tentang mata pelajaran ilmu sosial. Fokus penelitian ini adalah untuk mendeskripsikan desain perencanaan; implementasi, dan faktor-faktor yang mendukung serta menghambat bagi guru dalam melaksanakan pembelajaran. Penelitian ini menggunakan pendekatan kualitatif dan penelitian ini bersifat deskriptif. Dalam mengumpulkan data menggunakan metode observasi, wawancara, kuesioner dan dokumentasi. Hasil penelitian ini meliputi: pertama, Menentukan jenis media pembelajaran, membuat rencana pembelajaran, memperhatikan tujuan pembelajaran dalam memilih media, mengenali karakteristik siswa dan media pembelajaran; kedua, Teknik untuk mengelola kelas interaktif, langkah-langkah untuk mempresentasikan materi pengajaran, dan
\end{abstract}


menanggapi karakteristik siswa; dan ketiga, faktor pendukung meliputi: madrasah menyediakan fasilitas, kualitas guru yang memadai, minat siswa dalam media pembelajaran, motivasi siswa, keseriusan siswa untuk memperhatikan materi, dan pengaruhnya terhadap hasil belajar siswa. Sementara hambatannya adalah infrastruktur yang tidak memadai, dan keahlian guru kurang berpengalaman dalam mengoperasikan media google earth

Kata Kunci: Pola Pendidikan Agama Islam, Keluarga Petani

\section{Pendahuluan}

Menghadapi arus kehidupan globalisasi yang sedang terjadi maka pendidikan menuntut mampu menjawab persoalan-persoalan yang membutuhkan sebuah solusi, terutama menekankan pada pola pikir belajar yang mendekatkan siswa pada persoalan global terkait antara satu kondisi dengan kondisi lain yang saling memengaruhi, sehingga dalam kehidupan global harus disambut dengan globalnya pemikiran, luasnya jangkauan wawasan dan pengetahuan, serta penguasaan teknologi untuk menghadapi masa depan.

Pentingnya pendekatan teknologi dalam pengelolaan tersebut dimaksudkan agar dapat membantu proses pendidikan dalam pencapaian tujuan pendidikan. Penggunaan suatu media pada pembelajaran IPS (Ilmu Pengetahuan Sosial) secara kreatif dan inovatif akan memungkinkan bagi siswa untuk belajar lebih banyak dan siswa dapat memahami materi pelajaran dengan lebih baik, sehingga akan meningkatkan performan mereka sesuai dengan tujuan yang ingin dicapai.

Salah satu media digital yang sudah banyak digunakan oleh orang yaitu google earth. Google earth merupakan aplikasi berupa gambaran permukaan bumi atau objek tertentu dengan skala, gambar, garis, simbolsimbol melalui suatu sistem proyeksi. Penggunaan media pembelajaran google earth merupakan bagian dari IPTEK (Ilmu Pengetahuan dan Teknologi), sehingga dapat membantu guru dan siswa dalam proses belajar mengajar yang mengikuti perkembangan zaman. Hal ini sangat mendukung dalam peran media pembelajaran IPS terutama materi 
tentang peta dan globe melalui google earth. ${ }^{1}$

Sesuai dengan uraian tersebut, maka peneliti tertarik untuk melakukan penelitian terkait peran guru dalam media pembelajaran IPS (Ilmu Pengetahuan Sosial) pada materi tentang peta melalui google earth. Sejalan dengan itu peneliti mengajukan judul skripsi "Peran Guru dalam Penggunaan Media Peta Berbasis Google Earth di MIN 2 Kota Kediri".

Peneliti telah menyusun beberapa masalah yang akan dibahas dalam skripsi ini, berdasarkan latar belakang permasalahan. Adapun beberapa masalah yang akan dibahas antara lain meliputi:

1. Desain perencanaan guru dalam penggunaan media pembelajaran IPS melalui peta berbasis google earth di MIN 2 Kota Kediri.

2. Implementasi guru dalam penggunaan media pembelajaran IPS melalui peta berbasis google earth di MIN 2 Kota Kediri.

3. Faktor-faktor penunjang dan penghambat guru dalam penggunaan media pembelajaran IPS melalui peta

1 Soyomukti Nurani, Pendidikan Berspektif Global (Jogjakarta : Ar-Ruzz Media, 2008), h. 23. berbasis google earth di MIN 2 Kota Kediri.

\section{Metode}

Metode penelitian adalah cara atau jalan yang ditempuh untuk melakukan suatu penelitian. Dilihat dari bentuknya, metode penelitian pendidikan dibedakan dalam tiga katagori. Ketiga katagori tersebut adalah metode kualitatif, metode kuantitatif, dan metode fungsional. ${ }^{2}$

Pendekatan yang digunakan oleh penulis dalam penelitian ini adalah pendekatan kualitatif. "Pendekatan kualitatif adalah suatu prosedur penelitian yang menggunakan latar alamiah dengan maksud menafsirkan sebuah fenomena yang terjadi". ${ }^{3}$

Dalam penelitian ini menggunakan landasan teoritis yang dapat mendukung terlaksananya penelitian kualitatif. Dengan demikian peneliti membuat suatu instrument penelitian berupa pedoman wawancara dan pedoman angket bagi siswa untuk menganalisis dan menjelaskan sebuah rangkaian penelitian.

2 Jasa Ungguh Muliawan. Metodelogi Penelitian Pendidikan Dengan Studi Kasus (Yogyakarta: Gava Media, 2014), h. 60.

${ }^{3}$ Lexy J. Moleong, Metodologi Penelitian Kualitatif (Bandung: PT.Remaja Rosdakarya, 2010), h. 3. 
Sedangkan jenis penelitian yang digunakan dalam penelitian ini adalah metode diskriptif studi kasus. Metode diskriptif adalah metode penelitian yang berisi pemaparan atau penggambaran sesuatu, sedangkan studi kasus adalah penelitian mendalam mengenai unit sosial tertentu yang hasilnya merupakan gambaran yang lengkap dan terorganisasi baik mengenai unit tersebut. ${ }^{4}$

Penelitian dilakukan di MIN 2 Kota Kediri yang terletak di Jln. KH. Agus Salim. Gg. VIII, Kelurahan Bandar Kidul Kecamatan Mojoroto Kota Kediri. Alasan peneliti memilih penelitian di MIN 2 Kota Kediri dikarenakan objek penelitian tersebut termasuk lembaga pendidikan yang berstatus madrasah negeri milik pemerintahan setempat dan kualitas pembelajarannya terbilang sangat baik. Di samping itu guru yang mengajar di MIN 2 Kota Kediri senantiasa berinovasi dan mengembangkan media pembelajaran untuk diterapkan sebagai bahan pengajaran.

Untuk menggali data-data di lapangan dalam rangka untuk mengdeskripsikan dan mengkaji permasalahan yang dilakukan oleh peneliti,

4 Muliawan. Metodelogi Penelitian Pendidikan Dengan Studi Kasus, h. 84. 42 maka peneliti menggunakan metode pengumpulan data sebagai berikut:

\section{Hasil dan Pembahasan}

\section{Desain Perencanaan Pembelajaran}

Dalam metodologi pengajaran terdapat ada dua komponen yang paling berpengaruh yakni metode mengajar dan media pengajaran sebagai salah satu alat penunjang dalam pembelajaran yang efektif, sehingga diperlukan adanya media pembelajaran dalam menyampaikan isi materi. Sedangkan penilaian adalah salah satu alat untuk mengukur atau menentukan taraf tercapai-tidaknya tujuan pengajaran.

a. Jenis media pembelajaran yang digunakan

Dalam hal ini, peneliti melakukan koordinasi terkait judul skripsi ini dengan guru yang mengajar mata pelajaran IPS di MIN 2 Kota Kediri, guna memastikan sejauh mana pihak madrasah dalam menggunakan jenis media pembelajaran, namun berdasarkan kutipan hasil wawancara dengan Yuniati Rahayu Choiriyah selaku Kepala Madrasah mengatakan bahwa:

Media pembelajaran yang digunakan di MIN 2 Kota Kediri sangat bervariatif entah itu yang bersifat media audio, media visual, bahkan media audio visual online. Semua itu

el Bidayah: Journal of Islamic Elementary Education Volume 1, Nomor 2,September 2019 
sesuai dengan kebutuhan tiap tingkatan kelas dalam menyampaikan materi, namun kelas yang sudah teruji dalam penggunaan media pembelajaran berupa alat bantu proyektor yakni kelas V (lima) yang terdiri dari tiga rombel (rombongan belajar). ${ }^{5}$

Penggunaan media pembelajaran yang variatif dan inovatif mampu mengatasi sikap pasif peserta didik, sehingga dapat menumbuhkan kegairahan belajar, memungkinkan interaksi yang lebih langsung antara peserta didik dengan lingkungan dan kenyataan.

Berdasarkan hasil wawancara tersebut bahwa dalam proses belajar mengajar keberadaan media sangat penting fungsinya, dimana dengan menggunakan media pembelajaran guru diberi kemudahan dalam penyampaian isi materi dan siswa mudah untuk memahami materi yang disampaikan, sehingga hal ini penggunaan media jenis audio visual telah di terapkan di MIN 2 Kota Kediri.

b. Guru membuat rencana pembelajaran

Sebelum guru melaksanakan penggunaan media di kelasnya, ia harus mempersiapkan segala hal yang mendukung terhadap tahap implementasi dalam pengunaan media pembelajaran tersebut. Tanpa perencanaan yang baik, pelaksanaan pembelajaran tidak akan berjalan dengan lancar. Seperti halnya penuturan Lia Susanti, S.Pd. selaku guru mata pelajaran IPS kelas $5 \mathrm{C}$ bahwa:

Memang perangkat perencanaan media pembelajaran sangat diperlukan bagi guru untuk mempersiapkan apa yang akan dilakukan saat kegiatan belajar mengajar berlangsung. Kurikulum disini memakai kurikulum 2013 yang menekankan pada sikap afektifnya, sehingga guru dituntut benar-benar membuat perangkat perencanaan media pembelajaran semaksimal mungkin, karena kurikulum 2013 ini lebih ditekankan pada keaktifan peserta didik. Perangkat pembelajaran yang harus dibuat meliputi RPP, silabus, prota, promes sebagai acuan jangka panjang selama satu tahun dan satu semester, pekan efektif. 6

Dari data yang diperoleh peneliti dapat disimpulkan bahwa sebelum proses pembelajaran berlangsung, kesiapan guru dalam mengajar harus direncanakan terlebih dahulu. Adapun perencanaan guru dalam proses pembelajaran yaitu mempelajari silabus, membuat RPP, menentukan

5 Yuniati Rahayu Choiriyah, Wawancara, MIN 2 Kota Kediri, 11 Februari 2019.

${ }^{6}$ Lia Susanti, Wawancara, MIN 2 Kota Kediri, 13 Februari 2019. 
metode dan media yang akan digunakan.

c. Guru memperhatikan tujuan pembelajaran yang ingin dicapai dalam memilih penggunaan media

Tujuan adalah suatu keinginan yang akan dicapai dalam setiap kegiatan interaksi edukatif. Tujuan dapat memberikan pedoman yang terorganisir bagi guru dalam mempersiapkan segala sesuatunya dalam implementasi pembelajaran, termasuk pemilihan menggunakan media pembelajaran. Sebagaimana yang dikatakan oleh Lia Susanti, S.Pd. selaku guru mata pelajaran IPS kelas $5 \mathrm{C}$ bahwa:

Ketika memilih sebuah media pembelajaran yang akan digunakan maka yang kita harus perhatikan adalah tujuan apa yang akan dikuasai oleh siswa, setelah menerima pelajaran yang telah disampaikan, dan juga harus disesuaikan dengan kompetensi, kompetensi dasar maupun tujuan yang tercakup dalam indikator. ${ }^{7}$

Dari keterangan tersebut menunjukkan bahwa dalam hal memilih suatu media, guru harus mengetahui tujuan dari pembelajaran entah itu tujuan khusus maupun tujuan utama serta aspek-aspek yang diperlukan

7 Lia Susanti, Wawancara, MIN 2 Kota Kediri, 13 Februari 2019. untuk dikembangkan baik aspek kognitif, afektif maupun psikomotorik sehingga pembelajaran dapat efektif dan tidak menyimpang dari tujuan pengajaran tersebut.

d. Guru mampu mengenal karakteristik siswa ataupun perbedaan individual siswa

Perbedaan individual antar siswa perlu di pertimbangan dalam penggunaan media pembelajaran berupa google earth. Aspek-aspek perbedaan siswa yang perlu diamati adalah aspek biologis, intelektual, dan psikologis. Sehingga guru diharapkan dapat mengenal situasi dan kondisi siswa, karena dalam kegiatan pembelajaran siswa mempunyai latar belakang yang berbeda-beda, sebagaimana diungkapkan oleh Lia Susanti, S.Pd bahwa:

Dalam proses pembelajaran, siswa harus menjadi perhatian utama termasuk kesiapannya dalam mengikuti pelajaran yang akan disampaikan meliputi ada tidaknya motivasi, keadaan dan suasana kelas yang mendukung pembelajaran, Kesiapan siswa dalam mengikuti pelajaran tentu akan berpengaruh terhadap kegiatan dan hasil belajar. ${ }^{8}$

Selanjutnya diperkuat dengan hasil pengamatan peneliti "ketika

8 Lia Susanti, Wawancara, MIN 2 Kota Kediri, 13 Februari 2019.

el Bidayah: Journal of Islamic Elementary Education Volume 1, Nomor 2,September 2019 
mengikuti pelajaran di kelas. Sebelum memulai pelajaran guru menanyakan kepada siswa tentang kesiapan mereka mengikuti pelajaran, memberikan apersepsi sebelum dimulainya pelajaran dan dilanjutkan dengan mengecek kehadiran siswa". ${ }^{9}$

Berdasarkan data yang diperoleh dari hasil wawancara dapat dipahami bahwa kesiapan siswa dalam mengikuti proses pembelajaran akan berpengaruh terhadap kegiatan pembelajaran. Oleh sebab itu sebelum tahapan implementasi guru terlebih dahulu memperhatikan situasi kondisi dan kemampuan siswa dalam hal daya tangkap materi.

e. Guru mengetahui karakteristik media pembelajaran

Sebelum guru menggunakan media pembelajaran berupa google earth, maka guru harus mengetahui karakteristik dari media pembelajaran tersebut. Agar berlangsungnya proses belajar mengajar bisa berjalan secara efektif dan efisien. Sebagaimana yang dikatakan oleh Lia Susanti, S.Pd yang pada saat itu berada di ruang guru, beliau mengemukakan:

Penggunaan media google earth dalam proses belajar dapat

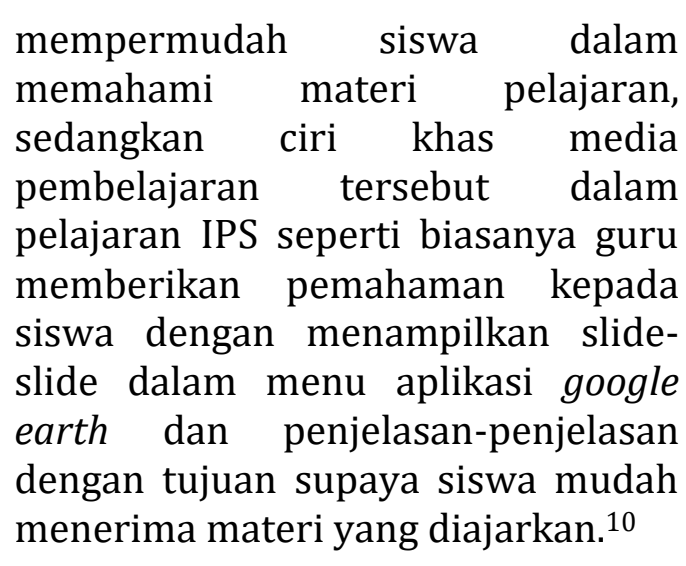

Berdasarkan data tersebut maka karakteristik media pembelajaran berupa google earth yaitu penyajian materi pelajaran IPS terutama pada materi tentang peta dengan menggunakan aplikasi yang dirancang berupa tampilan menu aplikasi dan slide, sehingga mempermudah guru beserta siswa dalam proses belajar mengajar yang menarik.

f. Guru mengetahui alokasi waktu

Pengalokasian waktu pada mata pelajaran IPS, yang di laksanakan di MIN 2 Kota Kediri adalah 90 menit dalam satu kali pertemuan. Sebagaimana ungkapan Hj. ST. Aminah, S.Pd.I selaku waka kurikulum bahwa:

Memang pada Madrasah ini alokasi waktu pada pembelajaran IPS 90 menit dalam satu kali pertemuan, Sehingga bagi guru IPS harus sebisa mungkin memanfaatkan waktu dengan

10 Lia Susanti, Wawancara, MIN 2 Kota Kediri, 13 Februari 2019. 
maksimal. Selian itu guru perlu memilih dan memilah materi yang akan disampaikan sesuai dengan kebutuhan. 11

Berdasarkan hasil data pengamatan peneliti bahwa:

Waktu 90 menit yang sangat singkat itu, dalam kegiatan pembelajaran harus semaksimal mungkin untuk dimanfaatkan dengan baik, terlebih menggunakan menggunakan $\mathrm{K}-13$, waktu yang digunakan untuk pendahuluan 10 menit kegiatan inti 65 menit dan penutup 15 menit. ${ }^{12}$

Dapat disimpulkan bahwa guru juga harus memperkirakan tentang waktu yang digunakan untuk kegiatan belajar mengajar dengan alokasi waktu 90 menit diperuntukkan untuk pendahuluan 10 menit kegiatan inti 65 menit dan penutup 15 menit. Waktu yang singkat agar diupayakan dalam kegiatan belajar mengajar tetap efektif dan sesuai dengan ketercapaian tujuan pembelajaran yang diinginkan.

\section{Implementasi Penggunaan Media}

Pembelajaran IPS Berupa Peta

\section{berbasis Google Earth}

Tahap implementasi atau tahap inti adalah tahap melakukan proses kegiatan pembelajaran IPS

11 ST. Aminah, Wawancara, MIN 2 Kota Kediri, 18 Februari 2019.

12 Observasi, MIN 2 Kota Kediri, 13 Februari 2019. 
serta tercapai sesuai tujuan pembelajaran. ${ }^{13}$

Dari hasil wawancara tersebut dapat ditarik kesimpulan bahwa peran guru harus mampu mengkondisikan siswa agar tetap konsentrasi dalam belajar. Oleh sebab itu usaha guru dalam mengelola siswa dengan cara menggunakan metode dan media yang sesuai dengan materi dapat memudahkan untuk menyampaikan materi, selain itu guru harus lebih kreatif dalam menyajikan materi, sehingga siswa tidak akan bosan dan tertarik untuk mengikuti pelajaran.

Dari observasi yang peneliti lakukan terlihat peran guru dalam menggunakan media berupa google earth pada pembelajaran IPS berjalan dengan baik dan siswa terlihat antusias mengikuti proses pembelajaran. ${ }^{14}$

b. Langkah-langkah penyajian bahan pengajaran

Standar Proses Pendidikan Dasar dan Menengah dibagi menjadi tiga kegiatan, yaitu pendahuluan, inti dan penutup. Sehingga proses pembelajaran IPS dimulai dengan kegiatan pendahuluan dengan mengucapkan

13 Lia Susanti, Wawancara, MIN 2 Kota Kediri, 13 Februari 2019.

14 Observasi, MIN 2 Kota Kediri, 18 Februari 2019. el Bidayah: Journal of Islamic Elementary Education Volume 1, Nomor 2, September 2019 salam, berdoa, absensi, memotivasi siswa, mencoba mengulang pelajaran lalu, menjelaskan tujuan pembelajaran yang akan dicapai, menanyakan pengalaman dengan mengaitkan tema yang akan dibahas, hal tersebut di perkuat dengan hasil penangamatan peneliti di lokasi, bahwa:

Ketika peneliti berada di lokasi, terlihat guru IPS saat masuk kelas dengan senyum seraya mengucapkan salam, dan membaca basmallah sebelum memulai pelajaran, selain hal tersebut guru tidak lupa mengabsen kehadiran peserta didik dalam mengikuti kegiatan pembelajaran yang akan berlangsung, serta menanyakan pengalaman yang pernah dilakukan saat dirumah maupun disekolah terkait tema yang akan dibahas. hal tersebut dilakukan guru untuk menyiapkan mental peserta didik, agar secara fisik dan bathinnya mampu menerima pelajaran yang akan disampaikan serta menjelaskan langkah kerja/metode. ${ }^{15}$

Berdasarkan hasil pengamatan tersebut, pelaksanaan guru dalam mengajar telah sesuai dengan standar proses pengajaran yang diawali dengan kegiatan pendahuluan dan pada kegiatan inti peran guru sangat berperan penting dalam mengatur berjalannya proses pembelajaran, sehingga guru harus mampu

15 Observasi, MIN 2 Kota Kediri, 27 Februari 2019. 
mengamati, bertanya, mengeksplorasi, mengasosiasi, dan berkomunikasi dengan siswa.

c. Respon karakteristik siswa ketika berlangsungnya proses pembelajaran

Pemanfaatan media google earth yang digunakan oleh guru kelas $5 \mathrm{C}$ dalam pembelajaran IPS mendapatkan hasil respon siswa yang positif. Sebagaimana penuturan Lia Susanti, S.Pd selaku guru IPS bahawa:

Penggunaan media google earth yang digunakan guru sebagai media pembelajaran dapat bermanfaat terhadap siswa dalam menerima materi yang disampaikan oleh guru, serta respon siswa sangat senang setelah media google earth digunakan pada pembelajaran, sehingga dalam proses pembelajaran berjalan kondusif dan siswa dapat menerima materi yang disampaikan dengan baik. ${ }^{16}$

Dari wawancara tersebut bisa disimpulkan bahwa dengan adanya media google earth siswa merasa senang, dan dapat menerima materi dengan baik serta mendapat respon yang baik.

Faktor-faktor Penunjang dan Hambatan dalam Penggunaan Media Pembelajaran IPS berupa Peta Berbasis Google Earth di MIN 2 Kota Kediri.

\footnotetext{
16 Lia Susanti, Wawancara, MIN 2 Kota Kediri, 27 Februari 2019. 48
}

Dengan mengenal dan memahami faktor-faktor penunjang yang mempunyai pengaruh terhadap keberhasilan proses pembelajaran IPS menggunakan media google earth, diharapakan mampu menjadi pertimbangan guru. Dalam hal pengumpulan data peneliti menggunakan metode observasi, wawancara, angket dan dokumentasi, sehingga peneliti juga memberikan lembar angket kepada siswa kelas 5 bagian C yang berjumlah 39 siswa mengenai tentang pemanfaatan media google earth yang telah digunakan oleh guru dalam pembelajaran IPS, hal ini untuk dijadikan tolak ukur dalam penerapan media pembelajaran berupa google earth yang dilakukan oleh guru.

Diantara faktor-faktor penunjang tersebut meliputi:

a. Pihak madrasah menyediakan fasilitas media pembelajaran

Media pembelajaran yang difasilitasi oleh madrasah cukup terbilang memadai, sebagaimana yang diungkapkan oleh Dra. Yuniati Rahayu Choiriyah, M.Pd.I selaku Kepala Madrasah mengatakan bahwa:

Fasilitas yang diberikan oleh sekolah untuk saat ini adanya Wifi, papan tulis, LCD, perpustakaan, lab komputer,dan lain-lain. Dalam pembelajaran IPS proses 
pembelajaran tidak harus dikelas, siswa bebas mengekspresikan dirinya di alam bebas saat belajar mengajar, suasana baru membuat semangat belajar meningkat. Pelajaran IPS sering melakukan kegiatan belajar di kelas. ${ }^{17}$

Berdasarkan pengamatan peneliti di lokasi. "Terlihat berbagai alat peraga yang digunakan sebagai media audio visual dalam proses pembelajaran yang dimiliki oleh pihak madrasah".18Sehingga keberadaan media pembelajaran tidak dapat terpisahkan dari proses belajar mengajar di sebuah madrasah guna tercapainya tujuan pendidikan pada umumnya dan tujuan pembelajaran di sekolah pada khususnya.

b. Kualitas guru pengajar memadai

Kualiatas guru yang profesional harus menguasai pengetahuan yang memadai dalam spesialisasinya. Penguasaan pengetahuan tersebut merupakan syarat penting di samping keterampilan-keterampilan lainnya yang dimiliki oleh guru. Peneliti telah melakukan wawancara kepada Lia Susanti, S.Pd selaku guru mata

17 Yuniati Rahayu Choiriyah, Wawancara, MIN 2 Kota Kediri, 13 Februari 2019.

18 Observasi, MIN 2 Kota Kediri, 11 Februari 2019. pelajaran IPS kelas $5 \mathrm{C}$, ia menuturkan bahwa,

Dalam pembelajaran IPS di kelas $5 \mathrm{C}$ telah menerapkan media pembelajaran berupa google earth dalam kegiatan belajar mengajar, hal ini tentunya berbekal kemampuan saya dalam menguasai materi sehingga bertujuan untuk memudahkan siswa dalam belajar pada pelajaran IPS dan terbukti siswa terlihat mengerti dan mudah menerima penjelasan materi yang saya sampaikan. ${ }^{19}$

Dari keterangan tersebut dapat dikatakan kegiatan belajar tanpa adanya guru yang memiliki kualitas mengajar yang professional tidak akan membawa kepada suatu tujuan pembelajaran. Mengingat pentingnya media terutama media google earth dalam pembelajaran IPS.

c. Ketertarikan siswa

Penggunaan media pembelajaran berupa google earth yang digunakan oleh guru mendapatkan respon baik bahkan seluruh siswa sangat tertarik dengan adanya penyampaian materi pelajaran. Hal tersebut sebagaimana dapat dilihat dari lembar angket yang peneliti bagikan kepada 39 siswa, bahwa 100\% semua siswa menyatakan atau menjawab sangat tertarik dan menyenangkan, sehingga tidak ada

${ }^{19}$ Lia Susanti, Wawancara, MIN 2 Kota Kediri, 27 Februari 2019. 
siswa yang menyatakan biasa-biasa saja atau merasa bosan dalam menerima materi pelajaran dengan menggunakan media pembelajaran google earth.

d. Motivasi siswa lebih memperhatikan materi pelajaran

Respon siswa dalam proses pembelajaran IPS menggunakan media google earth sangat termotivasi sebagaimana dilihat dari hasil lembar angket bahwa yang menyatakan sangat termotivasi sebanyak 36 siswa dan siswa yang menyatakan menerima pelajaran dengan jawaban biasa-biasa saja sebanyak 3 siswa, sedangkan yang tidak termotivasi dalam menerima pelajaran tidak ada.

e. Kesungguhan

siswa

memperhatikan materi

Dilihat dari tingkat kesungguhan siswa dalam memperhatikan materi pelajaran yang disampaikan oleh guru menggunakan media google earth sangat besar. Hal tersebut sebagaimana hasil lembar angket bahwa siswa yang menyatakan sangat memperhatikan materi pelajaran sebanyak 37 siswa, yang menyatakan biasa-biasa saja sebanyak 2 siswa dan yang menyatakan tidak memperhatikan tidak ada. Sehingga hal ini menunjukkan bahwa dengan adanya media google earth dalam proses belajar mengajar menjadi sangat menarik perhatian siswa di dalam memperhatikan materi pelajaran IPS.

f. Pengaruh pengguaan media google earth terhadap hasil belajar siswa

Penggunaan media pembelajaran google earth yang dilakukan oleh guru mata pelajaran IPS di kelas 5C mempunyai pengaruh terhadap hasil belajar siswa. Adapun yang menjadi tolak ukur terhadap hasil belajar siswa yaitu berupa hasil nilai, sehingga peneliti melakukan perbandingan hasil nilai antara setelah dan sesudah menggunakan media google earth. Sebagaimana penuturan Lia Susanti, S.Pd. selaku guru kelas $5 \mathrm{C}$ bahwa,

Sebelum guru menggunakan media google earth sebagai media pembelajaran, yang mana guru masih menggunakan peta konvensional sebagai media pembelajaran tentang peta. Maka berdasarkan hasil nilai yang di peroleh dari 39 siswa sebagai berikut: 12 siswa memperoleh nilai sangat baik, 20 siswa memperoleh nilai baik, 7 siswa memperoleh nilai kurang baik.

Berdasarkan hasil penilaian yang dilakukan oleh guru sebelum menggunakan media google earth menunjukan bahwa hasil nilai siswa yang memperoleh nilai sangat baik lebih rendah dari siswa yang el Bidayah: Journal of Islamic Elementary Education Volume 1, Nomor 2,September 2019 
memperoleh nilai baik. Namun setelah guru menggunakan media google earth menunjukan adanya peningkatan terhadap hasil nilai siswa, sebagaimana penuturan Lia Susanti selaku guru IPS bahwa,

Hasil nilai siswa setelah guru menggunakan media google earth cenderung menunjukan peningkatan pada 39 siswa dengan perincian 25 siswa yang memperoleh nilai sangat baik, 9 siswa memperoleh nilai baik dan 5 siswa memperoleh nilai kurang baik. ${ }^{20}$

Sehingga berdasarkan perbandingan yang diperoleh peneliti, bahwa sebelum dan setelah menggunakan media google earth menunjukan adanya peningkatan terhadap hasil nilai siswa dengan sangat baik.

Hambatan-hambatan guru dalam penggunaan media google earth pada mata pelajaran IPS di kelas 5C MIN 2 Kota Kediri diantaranya:

a. Sarana prasarana kurang memadai

Salah satu yang menjadi hambatan dalam implementasi pembelajaran menggunakan media google earth adalah tidak adanya proyektor di dalam ruang kelas, sehingga hal tersebut menjadikan waktu pengajaran terbuang karena

20 Lia Susanti, Wawancara, MIN 2 Kota Kediri, 27 Februari 2019. harus terlebih dahulu memasang proyektor. Sebagaimana wawancara dengan Lia Susanti, S.Pd selaku guru IPS kelas $5 \mathrm{C}$, beliau mengatakan:

Di ruang kelas sini proyektornya tidak terpasang secara permanen, sehingga saya setiap mau menggunakan media google earth harus terlebih dahulu mengambil proyektornya di kantor madrasah kemudian saya memasang sendiri di kelas. Akhirnya waktu pembelajaran terbuang karena harus mempesiapkan proyektornya dulu. ${ }^{21}$

Dari hasil wawancara tersebut dapat disimpulkan bahwa salah satu hambatan guru dalam penggunaan media google earth adalah tidak adanya proyektor yang sudah dipasang secara permanen di tiap kelas, sehingga guru terlebih dahulu mengambil di kantor madrasah.

b. Kurang berpengalaman dalam mengoperasikan media google earth

Menyajikan materi pelajaran IPS dengan menggunakan media google earth merupakan suatu keahlian guru yang bersangkutan, namun terkadang guru juga masih belum menguasainya sebagaimana yang telah dikatakan oleh Lia Susanti bahwa:

Saya sebenarnya belum begitu menguasai program aplikasi google earth secara keseluruhan, sehingga

21 Lia Susanti, Wawancara, MIN 2 Kota Kediri, 27 Februari 2019. 
terkadang merasa kesulitan dalam membuat tampilan yang menarik. Namun kalau hanya menampilkan menu yang terdapat di aplikasinya saya sudah lumayan bisa mas, dan saya terus berusaha belajar terkadang juga minta bantuan kepada guru yang lain apabila saya merasa kesulitan. ${ }^{22}$

Menurut keterangan dari hasil wawancara tersebut dapat disimpulkan bahwa kurangnya keahlian guru dalam menggunakan media google earth sebagai bahan pengajaran dengan tampilan semenarik mungkin sehingga menjadi hambatan bagi guru.

\section{Kesimpulan}

Setelah melalui rangkaian proses penelitian, pengkajian dan pengamatan yang peneliti lakukan di lapangan, maka peneliti memberikan kesimpulan sebagai berikut:

Pertama, desain perencanaan yang dilakukan oleh guru dalam penggunaan media pembelajaran IPS melalui peta berbasis google earth di MIN 2 Kota Kediri adalah menentukan jenis media pembelajaran, membuat rencana pembelajaran, memperhatikan tujuan pembelajaran yang ingin dicapai dalam memilih penggunaan media, mampu mengenal karakteristik dan

22 Lia Susanti, Wawancara, MIN 2 Kota Kediri, 27 Februari 2019. karakteristik media pembelajaran serta mengetahui alokasi waktu.

Kedua, implementasi guru dalam penggunaan media pembelajaran IPS melalui peta berbasis google earth di MIN 2 Kota Kediri adalah teknik mengelola kelas interaktif, langkahlangkah penyajian bahan pengajaran, dan respon karakteristik siswa ketika berlangsungnya proses pembelajaran.

Ketiga, faktor-faktor penunjang dalam penggunaan media pembelajaran IPS melalui peta berbasis google earth di MIN 2 Kota Kediri adalah Pihak madrasah menyediakan fasilitas terkait media pembelajaran, kualitas guru pengajar memadai, ketertarikan siswa, motivasi siswa, kesungguhan siswa memperhatikan materi, dan pengaruh pengguaan media google earth terhadap hasil belajar siswa. Sedangkan hambatannya adalah sarana prasarana kurang memadai, dan keahlian guru kurang berpengalaman dalam mengoperasikan media google earth.

\section{Daftar Pustaka}

Abdorrakhman, Gintings. Esensi Praktis Belajar dan Pembelajaran, Bandung: Humaniora, 2008.

Arifin, Imron. penelitian Kualitatif, Bandung: Kalimasahada Press, 1996 
Bakosurtanal. Membaca Peta Rupa Bumi

Indonesia. Jakarta: Badan

Standarisasi Nasional, 2004

Chalid, Latif dkk. Atlas Indonesia dan Dunia untuk Sekolah Lanjutan. Jakarta. PT. Pembina Peraga, 1997

Hadi, Sutrisno. Metode Research. Yogyakarta: Andi Offset, 2004

Moleong, Lexy J. Metodologi Penelitian Kualitatif. Bandung: PT. Remaja Rosdakarya, 2010

Muliawan, Jasa Ungguh. Metodelogi Penelitian Pendidikan Dengan Studi Kasus. Yogyakarta: Gava Media, 2014

Mulyana, Deddy. Metodelogi Penelitian Kualitatif, Bandung: Remaja Rosdakarya, 2001

Nurani, Soyomukti. Pendidikan Berspektif Global. Jogjakarta: ArRuzz Media, 2008

Poerwodarminto, W.J.S. Kamus Umum Bahasa Indonesia. Jakarta: Balai Pustaka, 1991

Sanjaya, Wina. Strategi pembelajaran: Berorientasi Standar Proses Pendidikan, Jakarta: Kencana, 2008

Sapriya. Pendidikan IPS. Bandung: PT.Remaja Rosdaya, 2009 